\title{
Employee Intention to Join a Union in Private University
}

\author{
Suguna Sinniah, Ramesh Kumar Moona Haji Mohamed, Syed Shah Alam, Ravindran Nadarajan, \\ Siti Fazilah Abdul Shukor, Che Natheera Banu Syed Abdul Aziz
}

\begin{abstract}
Trade unions are bodies that are not bound by any other organization and being free from the influence of employers makes them very powerful. Trade unions are also relationships between employers and their employees. Since the beginning of the 2008 financial crisis to now, there has been a decline in union membership of more than half a million. However, in this research, we found that unfair labour practices take the form of organization politics. Our main motive in this study was to identify the relationship between human resources practices and employee intention to join unions in the Malaysian education sector. We chose a particular university in Malaysia whose name is kept private and confidential. The study sample size was 120, which is sufficient for partial least squares structural equation modelling analysis. The study results reveal that the work environment, rewards, and compensation significantly influence employee intention to join a union. However, even if the employees intend to join the union, organizational politics moderate their decision to do so, and may prevent them from joining the union. The limitations of this study and suggested future research are also discussed.
\end{abstract}

Keywords: Career Development; Trade Union; Intention to Join Union.

\section{INTRODUCTION}

T rade union membership provides basic protection of the rights and welfare of workers. Theoretically, employees of all industries would be willing to join unions as doing so serves to strengthen the bargaining power of workers against unfair treatment in the workplace [1]. According to [2], all countries around the world have proficient a steady decline in union memberships since the 1990s. In the United Kingdom (UK), approximately 58 percent of employees were union members in 1979, but this total had fallen to around 25 percent by 2008. According to [3] (2014), the more than half million decline in union membership since 2008 can be attributed to the beginning of the financial crisis. In 2014, the author reported even lower participation in trade unions,

Revised Manuscript Received on 14 September, 2019.

* Suguna Sinniah

Suguna Sinniah*, Faculty of Business and Accountancy, SEGi University, Kota Damansara, Malaysia. Email: suguna@segi.edu.my

Ramesh Kumar Moona Haji Mohamed, Faculty of Business and Finance, University Tunku Abdul Rahman, Ipoh, Malaysia. Email: rameshk@utar.edu.my

Syed Shah Alam, Faculty of Business, Finance and Hospitality, MAHSA University Malaysia. Selangor, Malaysia. Syed@mahsa.edu.my

Ravindran Nadarajan, Faculty of Business and Finance, University Tunku Abdul Rahman, Ipoh, Malaysia.

Siti Fazilah Abdul Shukor,Faculty of Business and Finance, University Tunku Abdul Rahman, Ipoh, Malaysia.

Che Natheera Banu Syed Abdul Aziz, Faculty of Business and Finance, University Tunku Abdul Rahman, Ipoh, Malaysia. with 33,000 fewer members in the UK education sector. Moreover, the rate of union membership in the United States (US) has shown a steady decrease since the 1970s [4]. Several factors highlight related political issues via new laws that have rolled back the power of unions and the growth in unions with little presence in the workplace. The weakness of unions is also affecting Asian countries. Statistics from the Malaysian Ministry of Human Resources [5] reveal that a total of 722 trade unions are registered, with membership totalling 933,501 employees from different sectors. Furthermore, 57 of the 722 trade unions are registered in the education sector. The total membership in education trade unions is 341,610 of the 933,501 unionized employees in Malaysia, which represents a great portion of all the sectors. It also means that the education sector has greater influence in the trade union. Moreover, although trade union membership is not significantly declining in Malaysia, the percentage of union density has been lower for the past few decades [6]. Today, approximately $8 \%$ of Malaysian workers are unionized among all sectors and industries. In fact, in 2013, Malaysia had a lower density of union membership (9\%) than Australia (17\%), Japan (17.8\%) and even the US $(10.8 \%)$. These statistics indicate that employee interest in joining unions is low. In light of the decline in the overall density of trade union membership in Malaysia as well as other countries, researchers are questioning whether the current workforce does indeed have little interest in joining unions. For instances, [7] mentioned that strong trade unions can address undesirable and unpleasant situations that employees would like to improve in the workplace. Employees expect to secure improved pay and other benefits by joining trade unions. The author noted that Malaysia has a weaker trade union, which means weaker employee bargaining power in negotiation. However, employees who intend to join a union can be deterred from doing so by the organizational politics. According to [8], if organizational politics play a great role in an organization, workers rarely join unions even if the human resource management (HRM) in that organization is strong. In this study, we examined the connection between HR practices and the intention of employees to join unions in the Malaysian education sector. Although there have been many studies that have examined trade unions, few have focused on the education sector. Since the education sector has a strong membership in unions in Malaysia, a study of this issue in the education sector can serve as a model case with respect to trade unions. This approach can also provide information regarding the issue of the decline in trade union membership in other countries. It 


\section{Employee Intention to Join a Union in Private University}

is important to recognize the factors affecting the decline in union membership. Thus, this study is expected to be relevant to the current workforce and make workers aware of the challenges faced by Malaysian trade unions. In addition, the results of this study can provide guidance for trade union authorities and government parties regarding deficiencies in policies and practices. It is expected that certain amendments to the system can be made to address relevant organizational factors and obtain a better indulgent of the relationship between HR practices and the intention to join unions. For non-unionized workers, the study results can raise their awareness of trade unions and may increase the membership and union density of trade unions in Malaysia.

\section{LITERATURE REVIEW}

The intention to join unions varies from sector to sector. Overall, in this study, the independent variables in our proposed conceptual framework include three HRM practices. Our literature review reveals that relevant models have different research perspectives based on different model concepts. Researchers have found that training and development, rewards and compensation significantly influence employee commitment. Based on findings regarding the effect of rewards and compensation, career development and work-life policies, these three practices are believed to have a relationship to employee intention to join unions in the education sector [9]. When they are effectively implemented, these three practices can be expected to reduce the perceived risks and increase organizational commitment. Thus, the work environment is an additional variable to consider. Researchers have found that a comfortable and positive work environment with a low degree of organizational politics is subject to higher employee union membership [10]. The trade union is a body that is not bound by any other organization, and being free from the influence of any employer makes it very powerful. The trade union is also a connection between employers and their employees. The Trade Unions Act of 1959 defined trade unions as associations or affiliations between employees and employers with membership open to employees who perform the same type of work and are in the same industry. Thus, the proposed independent variables are believed to be significant related, either directly or indirectly, to the intention to join a union.

\section{A. Hypothesis development}

- Reward and compensation are negatively correlated with the intention to join a union, which is moderated by organizational politics.

According to [11], employers and trade unions must establish a good relationship to create an agreement that will benefit both parties. Using this theory, Hick also stated that trade unions could force employers to pay higher wages than the prescribed rates if the employers react stubbornly to the unions. This is because employers can face the threat of strike from employees who are forced to make their demands in this way. [12] also supported this theory in his book titled Problems of Monopoly and Economic Warfare. Despite the many driving factors that prompt workers to join trade unions, and the fact that the key function of trade unions is to work for the welfare of workers, there has been a decline in membership due to the presence of a high degree of organizational politics, as reported by [13]. From the discussion above, we propose the following hypotheses:

H1: There is a significant relationship between the rewards and incentives system and employee intention to join unions in the Malaysian education sector.

- Work-life balance policies are negatively correlated with the intention to join a union, which is moderated by organizational politics.

According to the study of [14], flexible and cost-effective work-life policies lead to a stronger organizational commitment and a decreased intention to leave one's work. With more humane HR policies, overall job satisfaction will increase and result in a high percentage of employee retention in an organization. Contemporary workplaces are more likely to offer flexibility with regard to work schedules and arrangements [15]. Fixed schedules and longer work hours are not preferred by the current workforce and result in higher turnover rates and absenteeism [16].

Hence, we propose that there is a positive theoretical relationship between work-life balance policies and employee commitment.

$\mathrm{H} 2$ : There is a significant relationship between work-life balance policies and employee intention to join unions in the Malaysian education sector.

H4: Organizational politics moderate the significant relationship between work-life balance policies and employee intention to join unions in the Malaysian education sector.

- Career development is negatively correlated with the intention to join a union, which is moderated by organizational politics.

The trade union may also affect the activities of institutions and regional organizations through their vocational training and apprenticeships. However, the objective of this study is to distinguish the differences between institutions that lead to inconsistencies in the HRM, organizational and cultural behaviours. Institutions will become more effective if they are democratically managed since this style has been found to facilitate management awareness of the needs of union members. If employer is responsive to their union needs, it is likely to leave its membership if the institution is indifferent in the case of high organizational politics [17].

H3: There is a significant relationship between career development and employee intention to join unions in the Malaysian education sector. 
H6: Organizational politics moderate the significant relationship between career development and the employee intention to join unions in the Malaysian education sector.

\section{METHODOLOGY}

The study population chosen by the researchers are employees at a particular university in Malaysia, which is not named in this paper for reasons of confidentiality. In partial least squares structural equation modelling (PLS-SEM) [18], a minimum sample size is required. The current population of the university is about 900, so we must ensure the minimum $\mathrm{R}^{2}(0.10,0.25,0.50$ and 0.75$)$ for any internal construct of the structural model for significance levels of $1 \%, 5 \%$ and $10 \%$ and to ensure a statistical power of $80 \%$ and a certain level of PLS complexity. Based on $\mathrm{G}^{*}$ Power method, the minimum sample requirement for this study is 85 . Normally, to determine the size of a sample, researchers can refer to the sample size determination table provided by [19] and [20]. For this study, we used a total population of 120 , based on the maximum number of arrows required for a sample size of 85 and we set the significant level of the study to $\mathrm{p}<0.05$ (5\% error) with a $95 \%$ confidence level.

We used a questionnaire adapted and developed from the literature to meet the objectives and address the questions of our study. The questionnaire contained four sections to be answered by the respondents in this case study. These sections include Part A- Respondent Demographics, Part B-HR Practices, Part C-Intention to Join Union and Part D-Organizational Politics. The answers used a 5-point Likert scales with 1 (Strongly Disagree), 2 (Disagree), 3 (Neutral), 4 (Agree) and 5 (Strongly Agree). Table 1 below shows the developed questionnaire items with the pilot study results:

Table 1: Sources of questionnaire

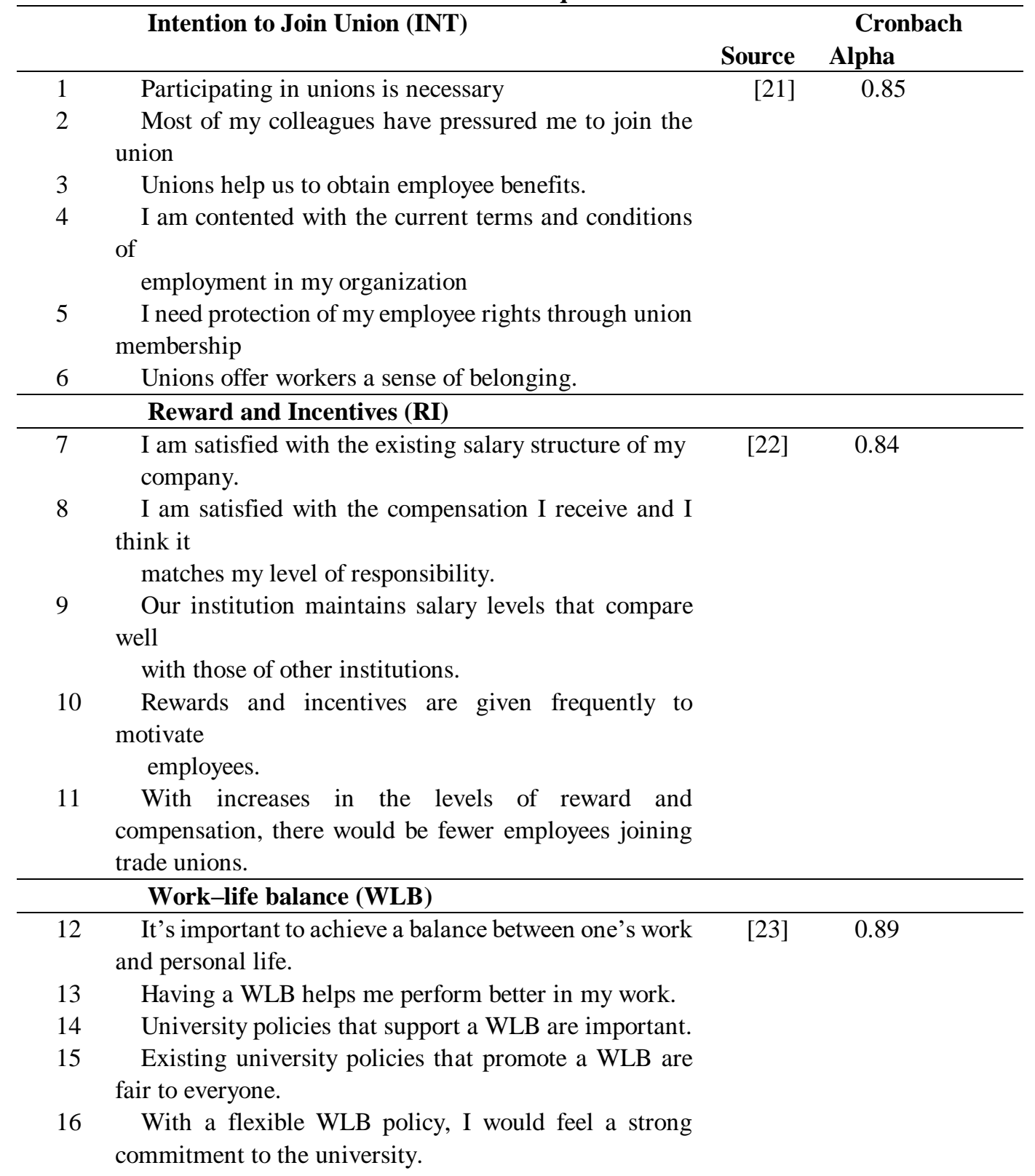




\section{Employee Intention to Join a Union in Private University}

\section{Career development (CD)}

exploit my career potential.

18 My organization helps me to obtain more work experience related to the work I do.

19 My organization provides me with opportunities to achieve my career goals.

20 My organization supports my long-term career development.

21 The overall career development opportunities at my university are satisfactory.

\begin{tabular}{lll}
\hline \multicolumn{3}{c}{ Organization politics (OP) } \\
\hline 22 & People in this organization attempt to build themselves $\quad[25]$ & 0.90 \\
& up by slashing down others. \\
23 & There is a influential group in my department that no \\
& one ever dares to cross. \\
24 & Pay and promotion is not applied politically. \\
25 & Existing policies are inappropriate, in pay raises and \\
& promotion decisions. \\
26 & Employees are encouraged to voice out their ideas. \\
27 & Agreeing with those who are powerful is the best \\
& alternative. \\
& Personal relationship with management carries a lot of \\
&
\end{tabular}

\section{RESULTS AND FINDINGS}

The loading values of the indicators of all the variables are $\geq 0.7$. A large loading value of each indicator construct above 0.7 means that the measurement of the constructs qualifies with respect to convergent validity [18] The reliability of the data can be tested by the composite reliability coefficients and Cronbach's alpha coefficients of all the variables. The reliability test results were all greater than 0.70 , which means that all the variables are reliable. The full collinearity (VIF) values of all the variables are less than 3.3, which means the model is free from vertical and lateral collinearity and common method bias [26]. In the model, the average variance extracted (AVE) from all constructs exceeds 0.5 [27], whereas the composite reliability (CR) score is higher than 0.7 [28]. Thus, we can state that convergent conclusions have been obtained.

Table 3. Convergent validity

\begin{tabular}{ccccccc}
\hline Items & Loadings & Cronbach's Alpha & rho_A & CR & AVE & VIF \\
\hline CD1 & 0.79 & 0.832 & 0.844 & 0.88 & 0.6 & 1.919 \\
CD2 & 0.823 & & & & & 2 \\
CD3 & 0.742 & & & & & 1.691 \\
CD4 & 0.791 & & & & & 1.658 \\
CD5 & 0.713 & & & & & 1.484 \\
INT1 & 0.856 & 0.879 & 0.884 & 0.91 & 0.67 & 2.413 \\
INT2 & 0.856 & & & & & 2.328 \\
INT3 & 0.844 & & & & & 1.714 \\
INT4 & 0.748 & & & & & 1.93 \\
INT5 & 0.797 & & & & & 2.147 \\
OP1 & 0.822 & 0.838 & 0.897 & 0.89 & 0.67 & 2.197 \\
OP2 & 0.798 & & & & & 2.247 \\
OP3 & 0.892 & & & & & 1.384
\end{tabular}




\begin{tabular}{ccccccc} 
OP4 & 0.743 & & & & 2.354 \\
RI1 & 0.903 & 0.814 & 0.817 & 0.89 & 0.73 & 1.769 \\
RI2 & & 0.836 & & & & \\
RI5 & & 0.823 & & & & \\
WLB1 & & 0.85 & 0.882 & 0.889 & 0.91 & 0.68 \\
WLB2 & 0.826 & & & & \\
WLB3 & 0.858 & & & & \\
WLB4 & 0.806 & & & & \\
WLB5 & 0.778 & & & \\
\hline
\end{tabular}

Table 3: Fornel and Larcker

\begin{tabular}{cccccc}
\hline & CD & IJU & OP & RI & BL \\
\hline CD & $\mathbf{0 . 7 7 3}$ & & & & \\
IJU & -0.447 & $\mathbf{0 . 8 2 1}$ & & & \\
OP & 0.196 & -0.277 & $\mathbf{0 . 8 1 6}$ & & \\
RI & 0.47 & -0.756 & 0.269 & $\mathbf{0 . 8 5 5}$ & \\
WLB & 0.48 & -0.538 & 0.29 & 0.601 & $\mathbf{0 . 8 2 4}$ \\
\hline
\end{tabular}

Table 4: HTMT \& model fit

\begin{tabular}{cccccccc}
\hline & CD & IJU & OP & RI & WLB & & Saturated Model \\
\hline CD & & & & & & SRMR & 0.07 \\
& 0.51 & & & & & d_ULS & 1.252 \\
IJU & 1 & & & & & & \\
& 0.24 & 0.28 & & & & d_G & 0.553 \\
OP & 9 & 9 & & & & Chi-Squar & \\
& 0.57 & & 0.30 & & & e & 371.133 \\
RI & 9 & 0.89 & 9 & & & \\
& 0.56 & 0.60 & 0.35 & 0.70 & & \\
WLB & 4 & 7 & 2 & 4 & & & \\
\hline
\end{tabular}

Table 5: Cross loadings

\begin{tabular}{cccccc}
\hline Items & CD & IJU & OP & RI & WLB \\
\hline CD1 & $\mathbf{0 . 7 9}$ & -0.295 & 0.184 & 0.364 & 0.447 \\
CD2 & $\mathbf{0 . 8 2 3}$ & -0.396 & 0.15 & 0.373 & 0.322 \\
CD3 & $\mathbf{0 . 7 4 2}$ & -0.275 & 0.257 & 0.443 & 0.383 \\
CD4 & $\mathbf{0 . 7 9 1}$ & -0.402 & 0.029 & 0.322 & 0.388 \\
CD5 & $\mathbf{0 . 7 1 3}$ & -0.326 & 0.188 & 0.338 & 0.335 \\
& & & -0.29 & -0.65 & \\
INT1 & -0.4 & $\mathbf{0 . 8 5 6}$ & 9 & 8 & -0.52 \\
& -0.36 & & -0.19 & -0.69 & -0.42 \\
INT2 & 7 & $\mathbf{0 . 8 5 6}$ & 7 & 3 & 8 \\
& -0.36 & & & & -0.37 \\
INT3 & 4 & $\mathbf{0 . 8 4 4}$ & -0.19 & -0.62 & 2 \\
& -0.30 & & -0.23 & -0.52 & -0.46 \\
INT4 & 8 & $\mathbf{0 . 7 4 8}$ & 8 & 9 & 4 \\
& -0.39 & & -0.21 & -0.58 & -0.42 \\
INT5 & 2 & $\mathbf{0 . 7 9 7}$ & 4 & 9 & 5 \\
OP1 & 0.151 & -0.179 & $\mathbf{0 . 8 2 2}$ & 0.19 & 0.201 \\
OP2 & 0.157 & -0.105 & $\mathbf{0 . 7 9 8}$ & 0.18 & 0.299 \\
OP3 & 0.215 & -0.299 & $\mathbf{0 . 8 9 2}$ & 0.265 & 0.264
\end{tabular}




\begin{tabular}{cccccc} 
OP4 & 0.101 & -0.229 & $\mathbf{0 . 7 4 3}$ & 0.206 & 0.206 \\
RI1 & 0.406 & -0.669 & 0.244 & $\mathbf{0 . 9 0 3}$ & 0.531 \\
RI2 & 0.378 & -0.649 & 0.296 & $\mathbf{0 . 8 3 6}$ & 0.461 \\
RI5 & 0.42 & -0.618 & 0.144 & $\mathbf{0 . 8 2 3}$ & 0.55 \\
WLB1 & 0.402 & -0.491 & 0.119 & 0.589 & $\mathbf{0 . 8 5}$ \\
WLB2 & 0.369 & -0.474 & 0.281 & 0.506 & $\mathbf{0 . 8 2 6}$ \\
WLB3 & 0.481 & -0.459 & 0.234 & 0.491 & $\mathbf{0 . 8 5 8}$ \\
WLB4 & 0.351 & -0.378 & 0.238 & 0.41 & $\mathbf{0 . 8 0 6}$ \\
WLB5 & 0.367 & -0.396 & 0.346 & 0.457 & $\mathbf{0 . 7 7 8}$ \\
\hline
\end{tabular}

Table 6: Hypotheses

\begin{tabular}{|c|c|c|c|c|c|c|c|c|c|c|}
\hline Hypothesis & $\begin{array}{l}\text { Beta } \\
\text { Value }\end{array}$ & $\begin{array}{l}\text { Std } \\
\text { Err }\end{array}$ & T-value & P Values & LL & UL & R2 & F2 & Q2 & Decision \\
\hline & & & & & -0.76 & -0.52 & 0.59 & 0.59 & 0.36 & \\
\hline RI -> IJU & -0.642 & 0.075 & 8.533 & 0 & 8 & 1 & 1 & 5 & 5 & Supported \\
\hline Moderating Effect RI & & & & & -0.10 & & & 0.00 & & \\
\hline$->\mathrm{IJU}$ & 0.044 & 0.098 & 0.453 & 0.325 & $\begin{array}{c}8 \\
-0.21\end{array}$ & 0.213 & & $\begin{array}{c}3 \\
0.01\end{array}$ & & Not supported \\
\hline WLB -> IJU & -0.091 & 0.084 & 1.081 & 0.14 & 8 & 0.062 & & 2 & & Not supported \\
\hline Moderating Effect & & & & & -0.34 & -0.02 & & 0.05 & & \\
\hline WLB -> IJU & -0.178 & 0.096 & 1.847 & 0.032 & $\begin{array}{c}5 \\
-0.21\end{array}$ & 6 & & $\begin{array}{c}1 \\
0.01\end{array}$ & & Supported \\
\hline CD $->$ IJU & -0.09 & 0.077 & 1.167 & 0.122 & $\begin{array}{c}2 \\
-0.10\end{array}$ & 0.04 & & $\begin{array}{c}4 \\
0.00\end{array}$ & & Not supported \\
\hline -> IJU & 0.042 & 0.088 & 0.479 & 0.316 & 3 & 0.186 & & 3 & & Not supported \\
\hline
\end{tabular}

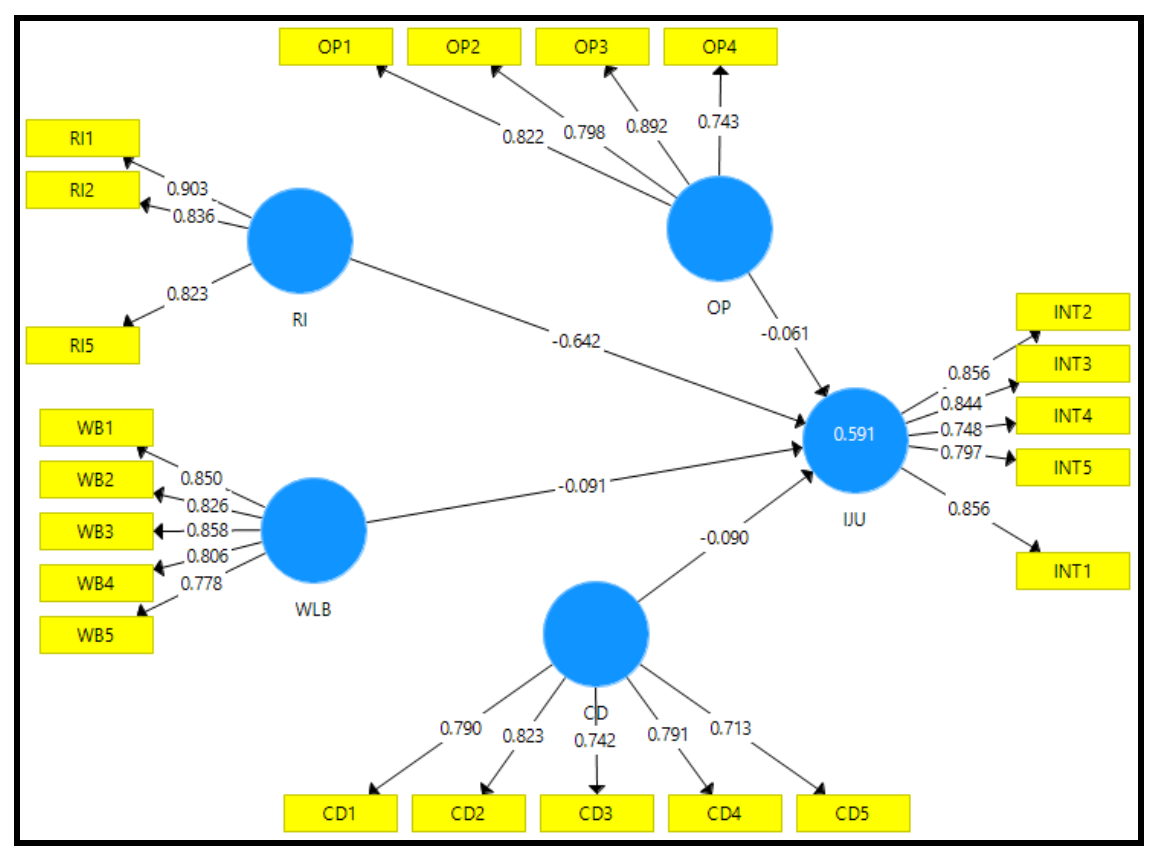

Figure 1: Measurement Model 


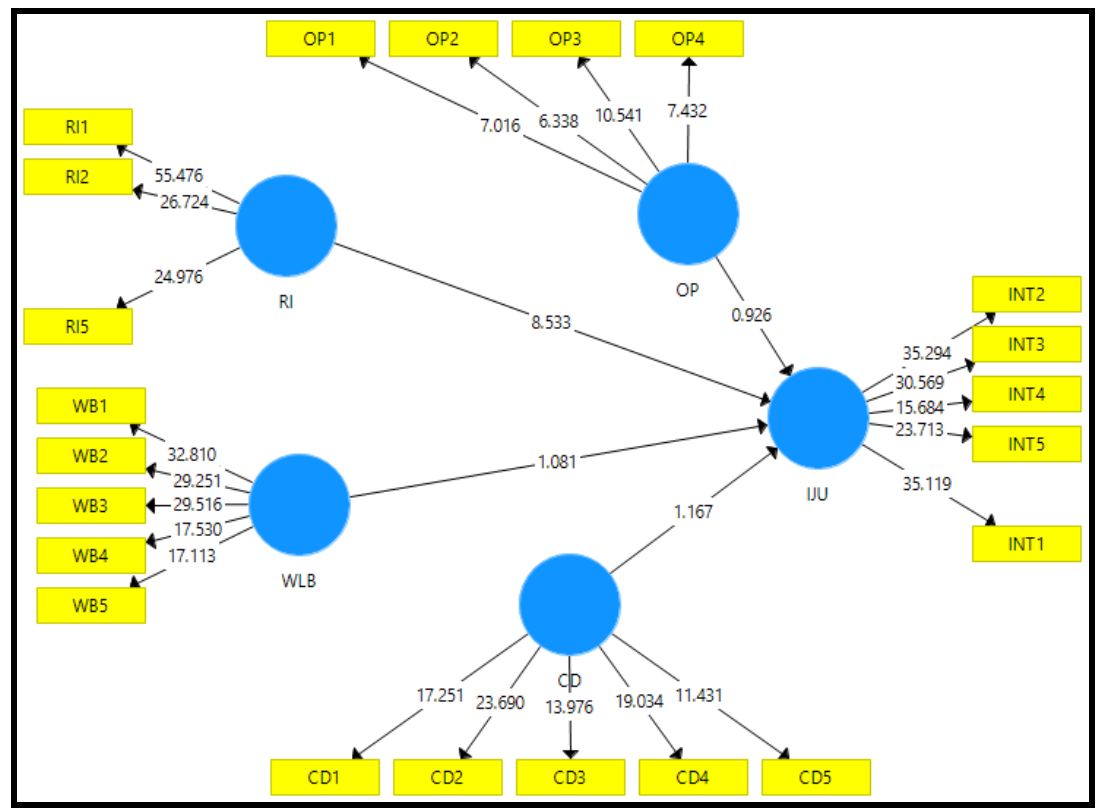

Figure 2: Structural Model

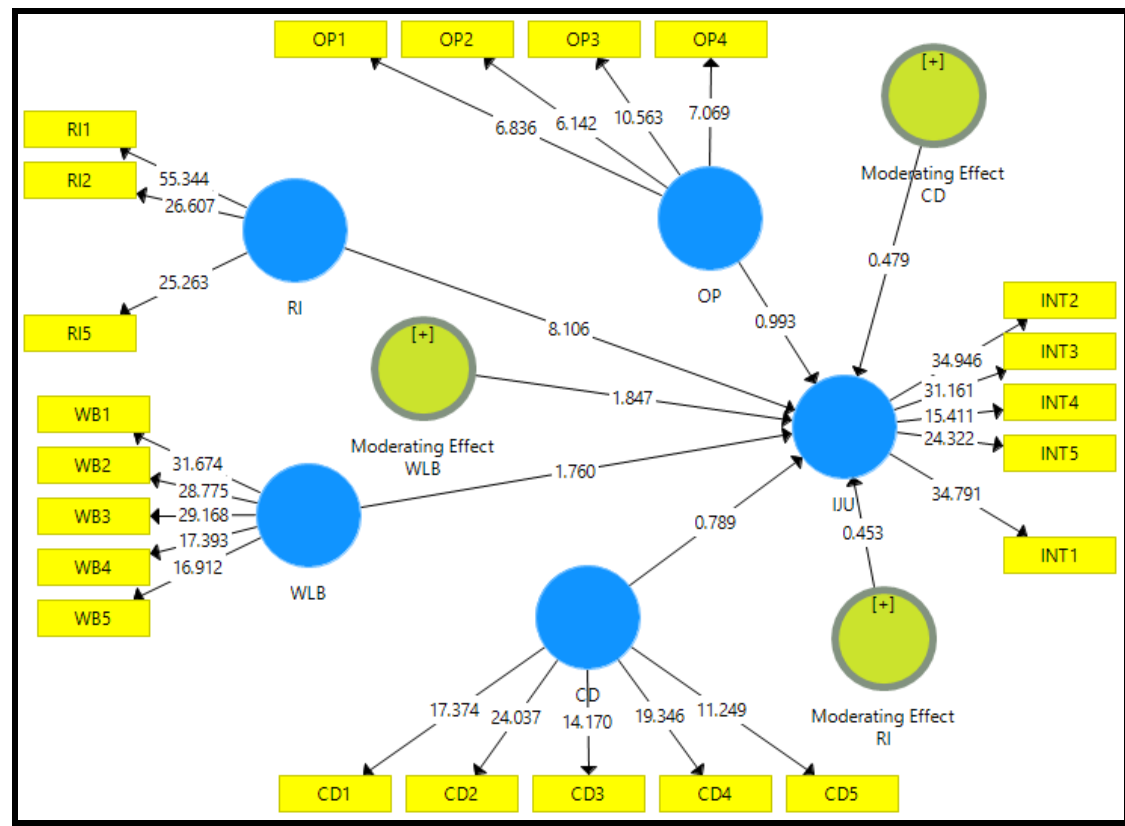

Figure 3: Moderator

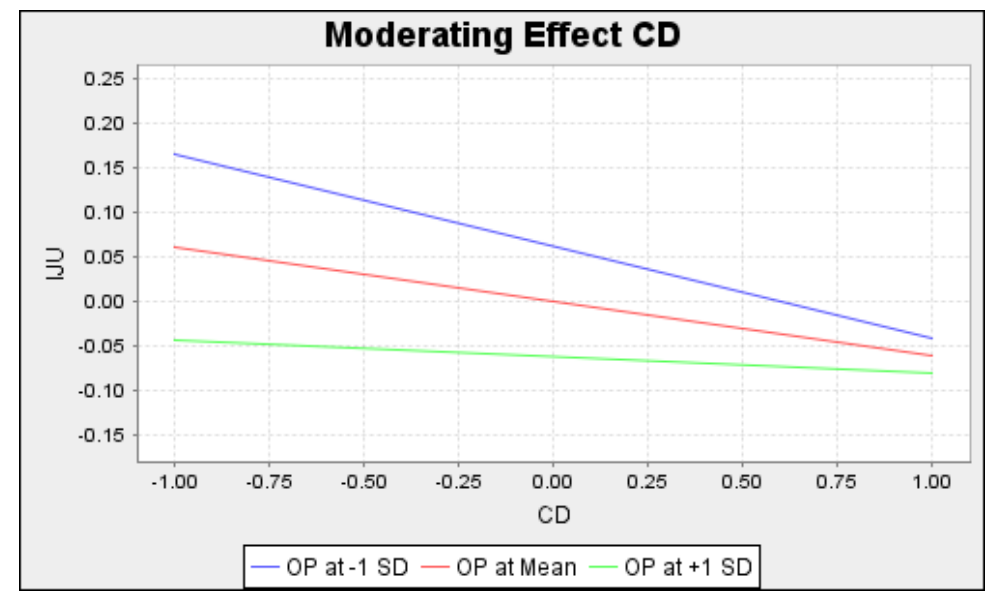

Figure 4: Moderator effect on CD 


\section{Employee Intention to Join a Union in Private University}

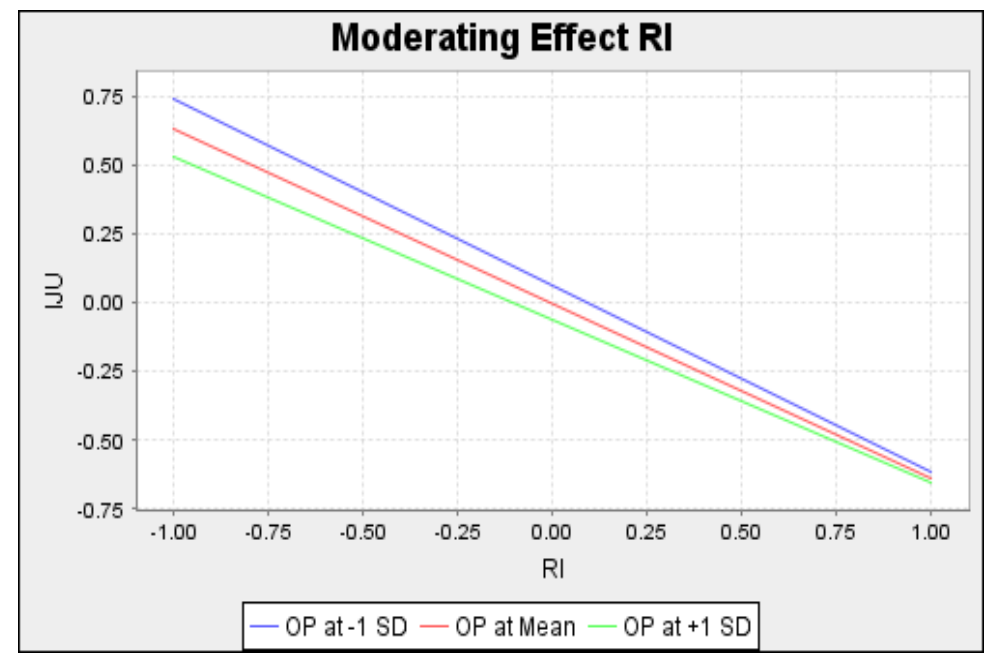

Figure 5: Moderator effect on RI

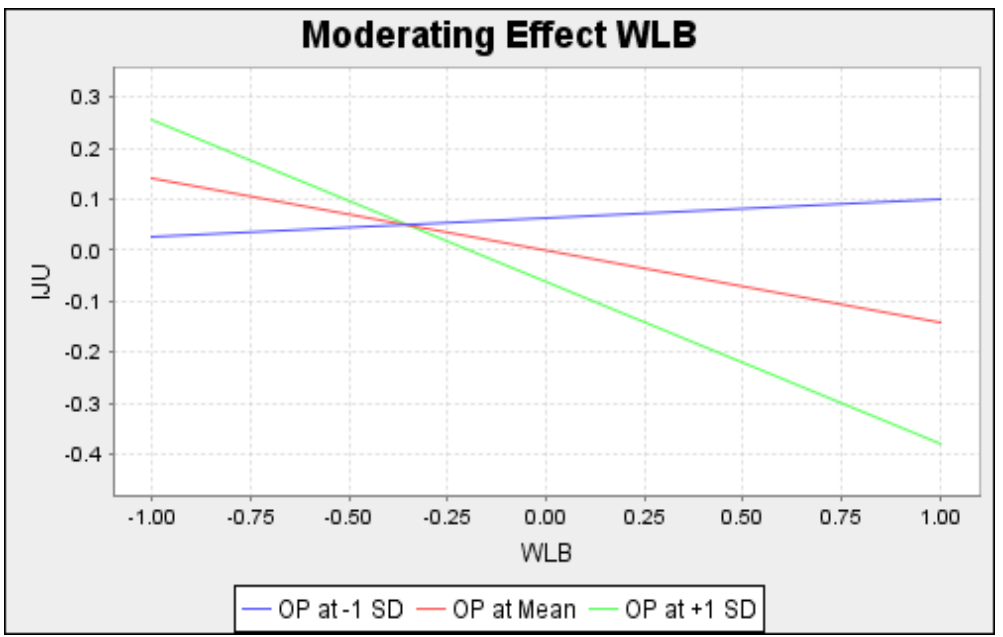

Figure 6: Moderator effect on WLB

Table 3 displays the outcome of the validity discrimination test. According to [29], each development in the construction model should be higher correlation between AVEs. As shown in Table 5, these constructions meet this criterion, which also shows that the construction has discrimination validity. [28], stated that, to meet the discrimination requirement, the measured variable load of items must be higher than their cross loads by at least 0.1 . Thus, we can conclude that the discrimination results are valid.A Monte Carlo simulation study was conducted by [30] to demonstrate the superior performance of their method, and we tested its discriminant validity in this study, the results of which are shown in Table 4. In assessing discriminant validity, two methods are used to determine the heterotrait-monotrait ratio of correlations (HTMT); the first of which is a criterion and the second is a statistical test. With respect to the first, issues can arise regarding the discriminant validity for HTMT values higher than 0.85 [31] or 0.90 [32].In measuring and assessing model fitness, we were guided by the work of [33]. These researchers state that the priority is to assess the saturated model and determine its standardized root mean square residual (SRMR), which shows the $95 \%$ bootstrap quantile. Doing so ultimately indicates that PLS-SEM can be only be fitted through the SRMR. In the PLS model fitness index [30], it is recommended that the geodesic discrepancy (dG) and unweighted least squares discrepancy (dULS) [32] provide additional ways to quantify the discrepancies between these distance measurement matrices. In Table 4, the dG and the dULS values are 0.553 and 1.252 , respectively, which verify that the model is very suitable for all [34]. As the SRMR is 0.070 , which is below the par value of 0.08 [35], this means that this measurement model is appropriate for this study.

\section{FINDINGS}

In this study, 120 respondents completed the questionnaire. In the pilot study test, the reliability value was above 0.80 , which indicates that the questionnaire is reliable and ideal. Table 7 shows the demographic profiles of the respondents. 
Table 7: Demographic profiles of respondents

\begin{tabular}{|c|c|c|c|c|c|}
\hline & & $\begin{array}{c}\text { Frequenc } \\
\mathbf{y} \\
\end{array}$ & $\begin{array}{c}\text { Percen } \\
\mathbf{t} \\
\end{array}$ & $\begin{array}{c}\text { Valid } \\
\text { Percent }\end{array}$ & Cumulative Percent \\
\hline \multirow{3}{*}{ Gender } & Male & 56 & 46.7 & 46.7 & 46.7 \\
\hline & Female & 64 & 53.3 & 53.3 & 100.0 \\
\hline & Total & 120 & 100.0 & 100.0 & \\
\hline \multirow[t]{5}{*}{ Age } & $18-25$ & 3 & 2.5 & 2.5 & 2.5 \\
\hline & $26-35$ & 41 & 34.2 & 34.2 & 36.7 \\
\hline & $36-44$ & 25 & 20.8 & -20.8 & 57.5 \\
\hline & 45-above & 51 & 42.5 & 42.5 & 100.0 \\
\hline & Total & 120 & 100.0 & 100.0 & \\
\hline \multirow[t]{5}{*}{ Ethnic } & Malay & 52 & 43.3 & 43.3 & 43.3 \\
\hline & Chinese & 36 & 30.0 & 30.0 & 73.3 \\
\hline & Indian & 31 & 25.8 & 25.8 & 99.2 \\
\hline & Others & 1 & .8 & .8 & 100.0 \\
\hline & Total & 120 & 100.0 & 100.0 & \\
\hline \multirow[t]{4}{*}{ Highest Education Level } & Master & 88 & 73.3 & 73.3 & 73.3 \\
\hline & $\mathrm{PhD}$ & 20 & 16.7 & 16.7 & 90.0 \\
\hline & Others & 12 & 10.0 & 10.0 & 100.0 \\
\hline & Total & 120 & 100.0 & 100.0 & \\
\hline Marital & Single & 25 & 20.8 & 20.8 & 20.8 \\
\hline \multirow[t]{3}{*}{ Status } & Married & 89 & 74.2 & 74.2 & 95.0 \\
\hline & Others & 6 & 5.0 & 5.0 & 100.0 \\
\hline & Total & 120 & 100.0 & 100.0 & \\
\hline
\end{tabular}

\section{RESULT OF THE SMART PLS 3.2.8 BOOTSTRAPPING RESULTS}

From the statistical analysis the results was obtained from 120 respondents. Low $\mathrm{t}$-statistical value of 1.65 for a $\mathrm{p} \leq$ 0.1 confidence interval was accepted by [28] (2014).On the other [36] recommended consecutive large, medium, and small effect sizes of $0.35,0.15$, and 0.02 . R2 values of 0.75 , 0.50 , and 0.25 indicating acceptable, satisfactory and poor values, respectively, were also reported by [37].

The identification of the $\mathrm{R}^{2}$ coefficient indicates the dependent constructs. As stated by Chin [37] (1998), a strong $\mathrm{R}^{2}$ requires a value of 0.67 , and a moderate value requires 0.33 , whereas a plunge to 0.19 is evidence of its weakness. However, [18] stated that an $\mathrm{R}^{2}$ of 0.75 is strong whereas 0.5 is moderate and 0.25 is below par or weak. In addition, [38] considered an $\mathrm{R}^{2}$ equal to or a little higher than 0.10 to indicate an endogenous construct. This has led to the development of a vigorous PLS bootstrapping method based on the consistent use of 5000 subsamples to obtain a level of significance [18]. Therefore, based on the findings of these researchers, as shown in Table 6 , we determined that an $\mathrm{R}^{2}$ of 0.591 is acceptable. Researchers are also encouraged to examine the F square value, also known as the effect size, which is used to determine the best models. As shown in Table 6 , the F score in this study is rather high, that is, a big effect size indicates that the applied model has also met the inner model requirement. In the same table, we can see that hypotheses $\mathrm{H} 1$ to $\mathrm{H} 6$ have been clearly identified and are aligned with the t statistics. At value higher than 1.645 ( $\mathrm{p}<$ $0.05)$ or higher than $2.33(\mathrm{p}<0.01)$ for the 1 -tail test, and a $\mathrm{t}$-value higher than $1.96(\mathrm{p}<0.05)$ or higher than $2.58(\mathrm{p}<$ 0.01 ) indicate significance. Table 6 reveals that hypotheses $\mathrm{H} 1$ and $\mathrm{H} 4$ are significant as they have positive values for their lower and upper limits, which assures $<0.05 \mathrm{P}$ value significance. However, the values of hypotheses H2, H3, H5 and $\mathrm{H} 6$ are not high enough and are thus insignificant.

\section{IMPLICATIONS AND CONCLUSION}

The results of this research provide insight regarding the impacts of different human resources practices on the intention to join unions. Theoretically, the research findings provide useful implications for trade union practitioners, union members, organization workforces, individuals and management to understand the concepts and relationship between unions and human resources practices. The essential task of unions is to help workforces fight against unfair organizational practices via collective bargaining. Generally, trade unions expect that an increase in the number of union members will strengthen the bargaining power of a pool of diverse employees. So, although union membership should be increasing, it is not. 


\section{Employee Intention to Join a Union in Private University}

The study results offer essential information about the issues associated with the decline in trade union membership. They provide a general understanding of the major problems and possible reasons for employees choosing to join a union or not. In this study, we examined the relationship of several human resources practices to the employee intention to join a union. The results indicate that only rewards and compensation significantly influence employee intention to join unions. Furthermore, even when employees intend to join a union, organizational politics can moderate this intention. In other words, organizational politics can deter them from joining a union when their concerns are related to their work-life balance which is related to a lot of internal politics. They may instead want to join the union because of the perceived lack of rewards and compensation. Therefore, unions should look into these issues of unfair labour practices, which may be indirect in nature. For instance, if the current educational workforce is not satisfied with the incentives, rewards and compensation provided by the organization, a strong intention to join a union implies an employee perception of ineffective practices in this regard. Management can use the results of this study as a reference for examining the root causes of employee dissatisfaction regarding organizational practices. In addition, policy makers can formulate better human resources practices that address employee welfare and benefits. In conclusion, in this research, we successfully identified and examined the significant relationship between the working environment, rewards and compensation and the leader-member exchange in influencing the intention to join unions. However, the results do not identify any significant relationship between training and development and work-life balance. Although these two independent variables did not meet the initial objectives hypothesized in the study, we recommend that other factors be considered and examined in future research by the use of other questionnaire formats. Future researchers are encouraged to further investigate this issue to build a stronger basic research team in collaboration with the Malaysian Trades Union Congress to better contribute to the Malaysian community.

\section{REFERENCES}

1. Barrows, T. S. (2017). What Do Unions Do to the Workplace? Union Effects on Management and HRM Policies. In What Do Unions Do? (pp. 283-320). Routledge.

2. Vachon, T. E., Wallace, M., \& Hyde, A. (2016). Union decline in a neoliberal age: Globalization, financialization, European integration, and union density in 18 affluent democracies. Socius, 2, 2378023116656847.

3. Hassel, A. (2014). The Paradox of Liberalization-Understanding Dualism and the Recovery of the $\mathrm{G}$ erman Political Economy. British Journal of Industrial Relations, 52(1), 57-81.

4. Jacobs, D., \& Dixon, M. (2010). Political partisanship, race, and union strength from 1970 to 2000: A pooled time-series analysis. Social Science Research, 39(6), 1059-1072.

5. Malaysian Ministry of Human Resources (2015) retrieved from http://www.mohr.gov.my/index.php/en

6. The Star. (2013, May 24). MTUC: Only $9 \%$ of workers in Malaysia unionised. Retrieved from The Star online: http://www.thestar.com.my/News/Nation/2002/12/12/MTUC-Only-9-of -workers-in-Malaysia-unionised/

7. Räthzel, N., \& Uzzell, D. (2012). Trade unions in the green economy: Working for the environment. Trade Unions in the Green Economy: Working for the Environment. https://doi.org/10.4324/9780203109670

8. Spagnoli, P., \& Balducci, C. (2017). Do high workload and job insecurity predict workplace bullying after organizational change?. International Journal of Workplace Health Management, 10(1), 2-12.

9. Maalik, A., Ahmed, N., \& Nazir, I. (2015). Impact of Work Life Balance, Career Development and Reward on Employee. Performance in Petroleum Sector of Pakistan.

10. Geppert, M., Williams, K., \& Wortmann, M. (2015). Micro-political game playing in Lidl: A comparison of store-level employment relations. European Journal of Industrial Relations, 21(3), 241-257. [17] Blau, P (2017). Exchange and power in social life. Routledge.

11. Zientara, P., \& Kuczyński, G. (2009). Employees' desire to join or leave a union: Evidence from Poland. Industrial Relations. https://doi.org/10.1111/j.1468-232X.2008.00550.x

12. Zeuthen, F. (1930). Problems of Monopoly and Economic Warfare, By F. Zeuthen. With a Pref. by Joseph A. Schumpeter.

13. Kim, S. E., \& Margalit, Y. (2017). Informed Preferences? The Impact of Unions on Workers' Policy Views. American Journal of Political Science, 61(3), 728-743

14. Grover, S. L., \& Crooker, K. J. (1995). Who appreciates family-responsive human resource policies: The impact of family-friendly policies on the organizational attachment of parents and non-parents. Personnel psychology, 48(2), 271-288.

15. Lahkar Das, B., \& Baruah, M. (2016). Work Life Balance: A Review of Literature.

16. Harhara, A. S., Singh, S. K., \& Hussain, M. (2015). Correlates of employee turnover intentions in oil and gas industry in the UAE. International journal of organizational analysis, 23(3), 493-504.

17. Blau, P. M. (2017). Exchange and power in social life. Exchange and Power in Social Life. https://doi.org/10.4324/9780203792643

18. Hair Jr, J. F., Hult, G. T. M., Ringle, C., \& Sarstedt, M. (2016). A primer on partial least squares structural equation modeling (PLS-SEM). Sage Publications.

19. Krejcie, R. V., \& Morgan, D. W. (1970). Determining sample size for research activities. Educational and psychological measurement, 30(3), 607-610.

20. Aguirre-Urreta, M., \& Rönkkö, M. (2015). Sample Size Determination and Statistical Power Analysis in PLS Using R: An Annotated Tutorial. CAIS, 36, 3.

21. Zientara, P., \& Kuczyński, G. (2009). Human resources practices and work-related attitudes in polish public administration. Eastern European Economics. https://doi.org/10.2753/EEE0012-8775470503

22. Rahimi, M., Hashim, M. T., Tahsildari, H., \& Khodakarmai, P. (2013) The Relationship between Perception of Equity and Job Satisfaction among Employees of Malaysian Universities. International Journal of Innovation and Business Strategy. https://doi.org/http://dx.doi.org/10.1080/17474086.2017.1399059

23. Mwangi, L., Boinett, C. C., Tumwet, E., \& Bowen, D. (2017). Effects of Work life Balance on Employees Performance in Institutions of Higher Learning. A Case Study of Kabarak University. Kabarak Journal of Research \& Innovation, 4(2), 60-69.

24. Tansel, A. \& Gungor, N. D. (2003). "Brain drain" from Turkey: Survey evidence of student non-return. Career Development International, 8(2), $52-89$

25. Kacmar, K. M., \& Ferris, G. R. (1991). Perceptions of organizational politics scale (POPS): Development and construct validation. Educational and Psychological measurement, 51(1), 193-205. [27] Fornell, C., \& Larcker, D. F. J. Cha (1994),"Partial Least Squares,". Advances Methods of Marketing Research, 52-78.

26. Yong, G. A., \& Pearce, S. (2013). A Beginner's Guide to Factor Analysis: Focusing on Exploratory Factor Analysis. Tutorials in Quantitative Methods for Psychology, 9(2), 79-94.

27. Bagozzi, R. P., \& Yi, Y. (1988). On the evaluation of structural equation models. Journal of the academy of marketing science, 16(1), 74-94

28. Fornell, C., \& Larcker, D. (1981). Evaluating Strutural Equation Models with Unobserved Variables and Measurement Error. Journal of Marketing Research, 18(1), 39-50. https://doi.org/10.1007/s13398-014-0173-7.2

29. Henseler, J., Ringle, C. M., \& Sarstedt, M. (2015). A new criterion for assessing discriminant validity in variance-based structural equation modeling. Journal of the academy of marketing science, 43(1), 115-135.

30. Henseler, J., Hubona, G., \& Ray, P. A. (2016). Using PLS path modeling in new technology research: updated guidelines. Industrial Management \& Data Systems, 116(1), 2-20. doi:10.1108/IMDS-09-2015-0382

31. Kline, R. (2010). Principles and practice of structural equation modeling. Structural Equation Modeling. https://doi.org/10.1038/156278a0

32. Gold, A. H., Malhotra, A., \& Segars, A. H. (2001). Knowledge management: An organizational capabilities perspective. Journal of Management Information Systems. https://doi.org/10.1080/07421222.2001.11045669 
33. Henseler, J., Hubona, G., \& Ray, P. A. (2016). Using PLS path modeling in new technology research: updated guidelines. Industrial Management \& Data Systems, 116(1), 2-20. doi:10.1108/IMDS-09-2015-0382

34. Dijkstra, T. K., \& Henseler, J. (2015). Consistent and asymptotically normal PLS estimators for linear structural equations. Computational Statistics \& Data Analysis, 81(1), 10-23 doi:10.1016/j.csda.2014.07.008

35. Hu, L. T., \& Bentler, P. M. (1999). Cutoff criteria for fit indexes in covariance structure analysis: conventional criteria versus new alternatives. Structural Equation Modeling, 6(1), 1-55.

36. Lowry, P. B., \& Gaskin, J. (2014). Partial Least Squares (PLS) Structural Equation Modeling (SEM) for Building and Testing Behavioral Causal Theory: When to Choose It and How to Use It. IEEE Transactions on Professional Communication, 57(2), 123-146

37. Sarstedt, M., Ringle, C. M., Smith, D., Reams, R., \& Hair Jr, J. F. (2014). Partial least squares structural equation modeling (PLS-SEM): A useful tool for family business researchers. Journal of Family Business Strategy, 5(1), 105-115.

38. Falk, R., \& Miller, N. B. (1992). A Primer for Soft Modeling. Open Journal of Business and Management.

\section{AUTHORS PROFILE}

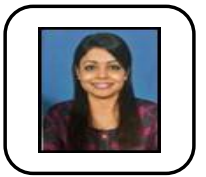

First Author Ms. Suguna Sinniah is a Senior Lecture at Faculty of Business, Accounting and Management, SEGi University, Kota Damansara. She has 13 years of experience in cooperate and academia. Her expertise is in the areas of human resource management, organizational behavior and international business. She has taught various subjects such as strategic management, organizational behavior, entrepreneurship, international business, business ethics and human resource management. She has published numerous papers in peer reviewed international journals as to date. Ms.Suguna holds a Master degree in Human Resource Management and Bachelor's degree in Business Administration. She is currently pursuing her $\mathrm{PhD}$ studies.

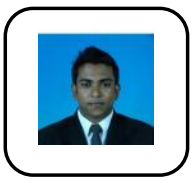

Second Author Dr. Ramesh Kumar currently is an Assistant professor for the Faculty of Business \& Finance, University Tunku Abdul Rahman (UTAR) Malaysia. He received his Master's degree in MBA from the University of Utara Malaysia (UUM). Graduate with B.Mgmt, (Hons) Major in Management and Minor in Political Science from the Universiti Sains Malaysia. He pursued his Ph.D. from USM in Human Resource Management field. He has more than 12 years of progressive Human Resource Executives experience and 12 years of teaching experience.

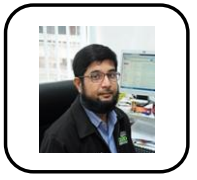

Third Author Dr. Syed Shah Alam is an Associate Professor at the Faculty of Business, Finance and Hospitality, Mahsa University Malaysia. Prior to joining to the Mahsa University Malaysia, he taught at Universiti Kebangsaan Malaysia, Universiti Teknologi MARA (UiTM), Malaysia and Multimedia University Malaysia (MMU). Dr Alam is the recipient of an "Excellent Service Award" at the Universiti Kebangsaan Malaysia in 2011. He has authored for four books on E-Commerce, Internet Marketing and Product Management published by Pearson and McGraw hill Malaysia. Over the past 15 years of teaching in Malaysia he has been actively involved in research. He has published more than 90 academic journal articles in business and E-commerce area including Q1 journals. He has served on roughly twenty conference and workshop program committees and served as the secretary for "First International Research Conference on Social Business' 2013" held in Universiti Kebangsaan Malaysia. His citation index $>3950$, h-index $>30$, i10-index $>54$. He has served as a reviewer for many reputed journals and currently serving as an editor for one Scopus journal. His research interest includes E-commerce, Internet Marketing, Consumer behavior, Entrepreneurship and Social Entrepreneurship.

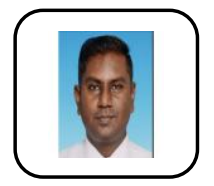

Forth Author Mr Ravindran Nadarajan, is an International Islamic University Malaysia's $\mathrm{PhD}$ Candidate, is a Law Lecturer at the Business Department of Faculty of Business and Finance, University Tunku Abdul Rahman. Mr Ravindran Nadarajan's work has been published in Legal journals including: International Journal Business, Economic, and Law and IIUM law journal. His current research on matrimonial law. His areas of interest on Matrimonial Family law matters, Industrial Relations, Employment Law and Current Issues in Human resource management. He was also an editor for LexisNexis and contributed to Legal
Terminology Books. He has provided training workshop on area of Industrial Relations and awareness for sexual harassment at workplace to one of leading manufacturing household electrical appliance, Panasonic Manufacturing Malaysia Berhad, Shah Alam. His areas of current research on implementation to wider the scope on matrimonial assets distribution for divorcee.

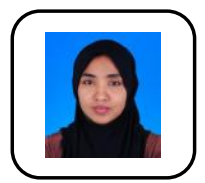

Fifth Author Ms Siti Fazilah Abdul Shukor is an International Islamic University Malaysia's $\mathrm{PhD}$ Candidate, and also a Law Lecturer at the Business Department of Faculty of Finance and Business, Universiti Tunku Abdul Rahman. She accomplished her Bachelor of Law and Commerce from MSU and her Master of Comparative Law from IIUM. She has been working as a lecturer for almost six years with the specializations on contracts, torts, employment, company, partnership and consumer law. Her current research area is the Employment and Industrial Relations Law. Besides, her interest areas are on Human Trafficking and Migration law matters, Consumer Protection law and any Current Issues on the aspect of law matters. Her work has published in Legal journals including Shariah Law Report a Journal on Islamic Law, Banking \& Finance, Jurnal Kanun and Journal of East Asia and International Law.

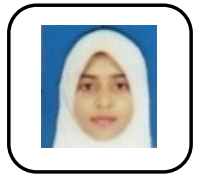

Sixth Author Puan Che Natheera Abdul Aziz is Sultan Azlan Shah's PhD Candidate, and also a Law Lecturer at the Business Department of Faculty of Finance and Business, Universiti Tunku Abdul Rahman. She accomplished her Bachelor of Law Hons and Master of Comparative Laws from IIUM. She has been working as a lecturer for almost sixteen years with the specializations on engineering law, contracts, torts, secretarial practice, company and legal system. Her current research area is on Islamic Family Law specializing child custody. Besides, she had written Islamic motivational books for public reading. 